BUDGETING : Journal of Business, Management and Accounting

Volume 1, Nomor 1, Desember 2019

e-ISSN: 2715-2480

p-ISSN: $2715-1913$

DOI : $\underline{\text { https://doi.org/10.31539/budgeting.v1i1.781 }}$

\title{
ANALISIS EARNING PER SHARE \\ DALAM MENINGKATKAN PENGEMBALIAN SAHAM
}

\author{
Bobby Billian Ramadhan ${ }^{1}$, Erry Sunarya ${ }^{2}$, Dicky Jhoansyah $^{3}$ \\ Univesitas Muhammadiyah Sukabumi ${ }^{1,2,3}$ \\ bouyaa021@gmail.com ${ }^{1}$
}

\begin{abstract}
ABSTRAK
Tujuan dari penelitian adalah untuk mengetahui perhitungan Earning Per Share (EPS) dan besarnya pengembalian saham pada perusahaan. Metode penelitian ini menggunakan teknik analisis deskriptif pendekatan kuantitatif yang digunakan untuk menggambarkan dalam mengukur tingkat pengembalian saham. Teknik analisis data menggunakan perhitungan Earning per Share dengan acuan dari kriteria standar ratarata industri. Hasil penelitian menunjukan bahwa diketahui secara teoritis ketiga perusahaan nilai dari EPS tidak baik karena hasil perhitungan dibawah standar ratarata industri. Simpulan tingkat pengembalian saham ketiga perusahaan menggunakan metode EPS menunjukan bahwa besar kecilnya EPS berperan penting dalam tingkat pembagian dividen.
\end{abstract}

Kata Kunci : Earning per Share, Pengembalian Saham, Laba Bersih

\begin{abstract}
Earning per share is profit per share which is a reference for investors in investing, the problems faced by PT. Indomobil Multi Jasa Tbk and PT. Buana Finance decreased its net income for two consecutive years. The purpose of the research is to find out the calculation of Earning Per Share (EPS) and the amount of stock returns on the company. This research method uses quantitative analysis descriptive analysis techniques that are used to describe in measuring stock returns. The data analysis technique uses Earning per Share calculations with a reference to the industry standard standard criteria. The results of the study show that theoretically the three companies value of EPS is not good because the calculation results are below the industry average standard. The results of the Earning per Share calculation can provide a reference for investors before deciding to invest to do an analysis of the company.
\end{abstract}

Keywords: Earning per Share, Stock Returns, Net Profit

\section{PENDAHULUAN}

Seiring perkembangan zaman yang semakin tahun semakin berkembang, pertumbuhan lembaga pembiayaan di Indonesia akan terus meningkat tiap tahunnya. Karena pertumbuhan lembaga pembiayaan di Indonesia tidak terlepas dari penduduk 
di Indonesia yang setiap tahunnya mengalami peningkatan. Dampak yang ditimbulkan dari berkembangnya lembaga pembiayaan di Indonesia salah satunya adalah untuk meningkatkan perekonomian nasional. Lembaga pembiayaan merupakan alternative sumber penyediaan dana atau barang modal. Karena manfaat dan kegunaannya sumber penyediaan dana telah menjadi kebutuhan masyarakat dalam kehidupan sehari-hari.

Disamping itu peluang bisnis bagi para pelaku usaha lembaga penyedia pembiayaan semakin lebar, dan menarik banyak investor luar negeri maupun dalam negeri untuk menanamkan modalnya. Pasar modal memiliki peranan penting dalam membangun perekonomian, dikarenakan pasar modal diibaratkan sebagai tempat atau wahana dunia usaha dan tempat untuk para investor dalam berinteraksi menjual atau membeli saham di perusahaan - perusahaan. Akan tetapi di dalam pasar modal ini persaingan semakin ketat, karena banyaknya para pelaku yang menggeluti dunia pasar modal. Untuk bertahan dalam menghadapi persaingan tersebut, maka perusahaan diharuskan mempunyai dan melaksanakan perencanaan dan strategi yang baik, agar perusahaan bisa bertahan dalam menghadapi persaingan dan mencapai tujuan yang diinginkan perusahaan. Dengan adanya persaingan tersebut perusahaan semakin terdorong dalam menjalankan usahanya dengan mencari dana yang akan menguntungkan perusahaan. Untuk pencarian dana tersebut, perusahaan membutuhkan investor yang akan memberikan suntikan dana untuk mengembangkan usaha yang akan dijalani oleh perusahaan. Akan tetapi tidaklah mudah untuk meminta suntikan dana kepada investor, banyak investor yang enggan menyuntikan dananya pada perusahaan yang memiliki kinerja yang kurang baik. Oleh karena itu informasi kinerja perusahaan memiliki peranan penting bagi para investor karena, kinerja perusahaan menggambarkan kondisi suatu perusahaan.

Kinerja perusahaan adalah prestasi yang dicapai oleh perusahaan dalam menjalankan usahanya yang mencerminkan apakah perusahaan tersebut dalam kondisi yang baik atau tidak (Raharjo, 2010). Jadi bisa disimpulkan bahwa kinerja perusahaan sangat dibutuhkan untuk mengevaluasi dan mengetahui sejauh mana tingkat keberhasilan perusahaan berdasarkan kinerja yang telah dilaksanakan. Karena investor cenderung memilih perusahaan yang memiliki kinerja yang baik maka, perusahaan yang memiliki kinerja yang baik membuat para investor tertarik untuk membeli saham 
perusahaan tersebut, dan sebaliknya jika perusahaan memiliki kinerja yang kurang baik maka para investor enggan membeli saham perusahaan tersebut. Semakin banyak saham yang dibeli, maka akan semakin meningkat pula harga saham perusahaan tersebut, dan akhirnya tingkat pengembalian saham (return saham) juga akan meningkat.

Return saham atau pengembalian saham merupakan keuntungan atau kerugian yang diperoleh investor dalam berinvestasi. Return saham bisa positif bisa juga negatif, jika positif berarti mendapatkan keuntungan atau mendapatkan capital gain dan dividen, sedangkan jika negative berarti mendapatkan kerugian atau mendapatkan capital lost. Dalam jual beli saham untuk meminimalisir kerugian yang didapat bisa diukur menggunakan Rasio Pasar. Rasio pasar adalah rasio yang menilai harga saham yang biasa digunakan oleh para investor sebelum menanamkan modalnya dan bertujuan untuk memaksimalkan nilai perusahaan dan kekayaan para pemegang saham. Selain itu, rasio ini memberikan petunjuk bagi para manajer perusahaan untuk mengikuti apa yang diinginkan oleh investor atas kinerja perusahaan di masa lalu serta di masa yang akan datang. Komponen rasio pasar salah satunya Earning Per Share (EPS).

Earning Per Share (EPS) atau Laba Per Saham merupakan rasio yang mengukur prestasi saham dan mencerminkan penilaian pemodal terhadap pengembalian (return). Rasio ini bisa menjadi patokan investor dalam menilai kekuatan profitabilitas setiap tahunnya, jika Earning Per Share (EPS) tinggi maka keuntungan yang dihasilkan oleh perusahaan juga akan tinggi yang akan berpengaruh terhadap pengembalian (return). Obyek yang digunakan penulis adalah PT Indomobil Multi Jasa Tbk , Buana Finance dan Batavia Prosperindo Finance yang bergerak di bidang lembaga pembiayaan dan merupakan salah satu perusahaan penyedia jasa keuangan terbesar di Indonesia. Alasan dipilihnya perusahaan tersebut karena laba bersih dari ketiga perusahaan tersebut mengalami penurunan yang cukup signifikan. Menurut Anggraini (2012) current ratio dan total asset turnonver berpengaruh positif terhadap price earning ratio. Sedangkan debt to equity ratio berpengaruh negative terhadap Price Earning Ratio. 


\section{KAJIAN TEORI}

Earning Per Share adalah laba per lembar saham pada sebuah perusahaan yang membuka sebuah investasi apabila rasionya tinggi maka kesejahteraan investor meningkat sedangkan apabila rasionya rendah maka sebuah perusahaan belum bisa memuaskan investor. Hal ini sesuai kiranya dengan pendapat Kasmir (2015) bahwa earning per share adalah rasio laba perlembar saham atau disebut juga rasio nilai buku merupakan rasio untuk mengukur keberhasilan manajemen dalam mencapai keuntungan bagi para pemegang saham. Sesuai juga dengan pendapat Fahmi (2015) Menyatakan bahwa Earning per share atau pendapatan perlembar saham adalah bentuk pemberian keuntungan yang memberikan kepada para pemegang saham dari setiap lembar saham yang dimiliki.

Pengembalian saham (Return Saham) adalah tingkat keuntungan yang akan diperoleh investor atas suatu investasi yang dilakukannya. Tanpa adanya tingkat keuntungan yang diperoleh dari suatu investasi maka, tentunya investor tidak akan melakukan investasi. Menurut Tandelilin (2010) mendefinisikan return saham merupakan salah satu faktor yang memotivasi investor berinvestasi dan juga merupakan imbalan atas keberanian investor menanggung resiko atas investasi yang dilakukan.

\section{METODE PENELITIAN}

Metode penelitian yang digunakan peneliti untuk menemukan dan mendapatkan sebuah jawaban untuk masalah yang di teliti adalah metode penelitian deskriptif dengan pendekatan kuantitatif. Dengan maksud, dalam penelitian ini peneliti akan mengambarkan atau menyimpulkan suatu prediksi bankcruptcy setelah melakukan perhitungan melalui model z-score modifikasi.

Data penelitian terdiri dari data sekunder. Yaitu data yang diperoleh secara tidak langsung dari situs web.idx.id dan www.idx.id yakni berupa data laporan keuangan PT. Indomobil Multi Jasa Tbk, PT. Batavia Prosperindo Tbk dan PT. Buana Finance Tbk dalam periode 2013-2015, yang dijadikan unit analisis dengan menggunakan teknik yang ada, maupun dari sumber yang di teliti serta data yang di dapat dari buku dan informasi lainnya maupun kepustakaan. 


\section{HASIL PENELITIAN}

\section{Perbandingan Standar Rata-Rata Industri}

Perhitungan rata-rata industri ini dapat digunakan untuk membandingkan nilai dari Earning per Share dari perusahaan yang sejenis. Berikut ini adalah hasil perhitungan Earning per Share pada perusahaan subsector lembaga pembiayaan yang terdaftar pada Bursa Efek Indonesia.

Tabel 1

Standar Rata-Rata Industri Earning Per Share

\begin{tabular}{lc}
\hline \multicolumn{1}{c}{ Perusahaan } & Earning Per Share \\
\hline Adira Dinamika Multi Finance Tbk & 1,7 \\
\hline Buana Finance Tbk & 82,4 \\
\hline BFI Finance Indonesia Tbk & 333 \\
\hline Batavia Prosperindo Finance Tbk & 36,28 \\
\hline Clipan Finance Tbk & 88,1 \\
\hline Danasupra Erapacific Tbk & 31,83 \\
\hline Radana Bhaskara Finance Tbk & 11 \\
\hline Indomobil Multijasa Tbk & 31,36 \\
\hline Mandala Multi Finance Tbk & 195 \\
\hline Tifa Finance Tbk & 29,25 \\
\hline Verena Multi Finance Tbk & 34,49 \\
\hline Standar Rata-Rata Industri Earning per Share $\mathbf{2 0 1 3}$ & $\mathbf{7 9 , 4 9}$ \\
\hline
\end{tabular}

Sumber : Hasil Penelitian, diolah 2019

Tabel 2

Standar Rata-Rata Industri Earning Per Share

\begin{tabular}{lc}
\hline \multicolumn{1}{c}{ Perusahaan } & Earning Per Share \\
\hline Adira Dinamika Multi Finance Tbk & 0,79 \\
\hline Buana Finance Tbk & 67 \\
\hline BFI Finance Indonesia Tbk & 385 \\
\hline Batavia Prosperindo Finance Tbk & 40,25 \\
\hline Clipan Finance Tbk & 83,1 \\
\hline Danasupra Erapacific Tbk & 91,10 \\
\hline Radana Bhaskara Finance Tbk & 25 \\
\hline Indomobil Multijasa Tbk & 29,06 \\
\hline Mandala Multi Finance Tbk & 232 \\
\hline Tifa Finance Tbk & 33,62 \\
\hline Verena Multi Finance Tbk & 24,43 \\
\hline Standar Rata-Rata Industri Earning per Share 2014 & $\mathbf{9 1 , 9 4}$ \\
\hline Sumber $:$ Hasil Peneliti, diolah 2019
\end{tabular}

Tabel 3

Standar Rata-Rata Industri Earning Per Share

\begin{tabular}{lc}
\hline \multicolumn{1}{c}{ Perusahaan } & Earning Per Share \\
\hline Adira Dinamika Multi Finance Tbk & 0.66 \\
\hline Buana Finance Tbk & 37 \\
\hline BFI Finance Indonesia Tbk & 417 \\
\hline Batavia Prosperindo Finance Tbk & 63,5 \\
\hline
\end{tabular}




\begin{tabular}{lc}
\hline Clipan Finance Tbk & 71,87 \\
\hline Danasupra Erapacific Tbk & 0,92 \\
\hline Radana Bhaskara Finance Tbk & 21 \\
\hline Indomobil Multijasa Tbk & 18,98 \\
\hline Mandala Multi Finance Tbk & 186 \\
\hline Tifa Finance Tbk & 18,58 \\
\hline Verena Multi Finance Tbk & 2,41 \\
\hline Standar Rata-Rata Industri Earning per Share 2015 & $\mathbf{7 6 , 1 7}$ \\
\hline
\end{tabular}

Sumber : hasil peneliti, diolah 2019

\section{Analisis Earning per Share dalam Meningkatkan Pengembalian Saham}

Penelitian ini menggunakan laporan keuangan dari PT Indomobil Multijasa Tbk, PT Batavia Finance Tbk dan PT Buana Finance Tbk selama tiga tahun yaitu dari tahun 2013 sampai dengan tahun 2015 untuk mengetahui perhitungan nilai Earning per Share dan seberapa besar tingkat pengembalian sahamnya.

\section{Earning per Share}

Earning per Share Merupakan rasio yang mengukur prestasi saham dan mencerminkan penilaian pemodal terhadap pengembalian (return). Rasio ini bisa menjadi patokan investor dalam menilai kekuatan profitabilitas setiap tahunnya, karena profit merupakan salah satu alat ukur utama kesuksesan suatu perusahaan. Oleh karena itu para investor seringkali memusatkan perhatiannya pada besarnya Earning Per Share dalam melakukan analisis saham. jika Earning Per Share (EPS) tinggi maka keuntungan yang dihasilkan oleh perusahaan juga akan tinggi. Rumus untuk menghitung Earning Per Share adalah sebagai berikut:

$$
\text { Earning Per Share }=\frac{\text { Laba bersih setelah pajak }}{\text { Jumlah saham yang beredar }}=\frac{135.666 .532 .052}{4.325 .000 .000}=31,36
$$

Berikut adalah hasil rekapitulasi dari perhitungan Earning per Share pada PT. Indomobil Multijasa Tbk. Periode 2013-2015.

\section{Tabel 4}

Hasil Rekapitulasi Perhitungan Earning Per Share

\begin{tabular}{ccccc}
\hline Tahun & $\begin{array}{c}\text { Laba Bersih Setelah } \\
\text { Pajak }\end{array}$ & $\begin{array}{c}\text { Jumlah Saham } \\
\text { Beredar }\end{array}$ & $\begin{array}{c}\text { Standar Rata- } \\
\text { Rata Industri }\end{array}$ & $\begin{array}{c}\text { Earning per } \\
\text { Shares }\end{array}$ \\
\hline 2013 & 135.666 .532 .052 & 4.325 .000 .000 & 79,49 & 31,36 \\
\hline 2014 & 125.703 .694 .455 & 4.325 .000 .000 & 91,94 & 29,06 \\
\hline 2015 & 82.121 .316 .194 & 4.325 .000 .000 & 76,17 & 18,98 \\
\hline
\end{tabular}

Sumber : Data Peneliti, 2019 
Berdasarkan tabel 4 diatas pada PT. Indomobil Multijasa Tbk mengalami penurunan laba bersih selama 2 tahun berturut-turut, penurunan laba bersih tersebut berdampak pada penurunan nilai Earning per Share. Dapat diketahui bahwa nilai Earning per Share mengalami penurunan selama 2 tahun berturut - turut yakni pada tahun 2014 sampai 2015. Hal tersebut Pada tahun 2013 laba bersih perusahaan sebesar 135.666.532.052 dan jumlah saham yang beredar sebesar 4.325.000.000 menghasilkan perhitungan nilai Earning per Share sebesar 31,36. Kemudian pada tahun 2014 laba bersih perusahaan mengalami penurunan dari 135.666.532.052 menjadi 125.703.694.455 akan tetapi, jumlah saham yang beredar tetap sebesar 4.325.000.000 dan hasil perhitungan nilai Earning per Share pada tahun 2014 mengalami penurunan dari 31,36 menjadi 29,06. Tahun 2015 mengalami penurunan laba bersih dari 125.703.694.455 menjadi 82.121.316.194 tetapi jumlah saham yang beredar tetap sebesar 4.325.000.000 dan hasil perhitungan nilai Earning per Share pada tahun 2015 mengalami penurunan yang cukup signifikan dari 29,06 menjadi 18,98.

Tabel 5

Hasil Rekapitulasi Perhitungan Earning Per Share

\begin{tabular}{cccc}
\hline Tahun & Laba Bersih Setelah Pajak & $\begin{array}{c}\text { Jumlah Saham } \\
\text { Beredar }\end{array}$ & Earning per Shares \\
\hline 2013 & 36.279 .199 .826 & 1.000 .000 .000 & 36,28 \\
\hline 2014 & 40.477 .000 .000 & 1.012 .134 .000 & 40,25 \\
\hline 2015 & 64.292 .000 .000 & 1.012 .134 .000 & 63,5 \\
\hline
\end{tabular}

Sumber: data diolah 2019

Berdasarkan tabel 5 diatas pada PT. Batvia Prosperindo Tbk mengalami kenaikan laba bersih setiap tahunnya, kenaikan laba bersih tersebut berdampak pada kenaikan nilai Earning per Share. Dapat diketahui bahwa nilai Earning per Share mengalami kenaikan selama 2 tahun berturut - turut yakni pada tahun 2014 sampai 2015. Hal tersebut Pada tahun 2013 laba bersih perusahaan sebesar 36.279.199.826 dan jumlah saham yang beredar sebesar 1.000.000.000 menghasilkan perhitungan nilai Earning per Share sebesar 36,28. Kemudian pada tahun 2014 laba bersih perusahaan mengalami kenaikan dari 36.279.199.826 menjadi 40.477.000.000 akan tetapi, jumlah saham yang beredar mengalami kenaikan dari tahun sebelumnya sebesar 1.012..134.340 dan hasil perhitungan nilai Earning per Share pada tahun 2014 mengalami keniakan dari 36,28 menjadi 40,25. Tahun 2015 mengalami kenaikan laba bersih dari 40.477.000.000 menjadi 64.292.000.000 tetapi jumlah saham yang beredar 
tetap sebesar 1.012..134.340 dan hasil perhitungan nilai Earning per Share pada tahun 2015 mengalami kenaikan yang cukup signifikan dari 40,25 menjadi 63,5.

Tabel 6

Hasil Rekapitulasi Perhitungan Earning Per Share

\begin{tabular}{cccc}
\hline Tahun & Laba Bersih Setelah Pajak & $\begin{array}{c}\text { Jumlah Saham } \\
\text { Beredar }\end{array}$ & Earning per Shares \\
\hline 2013 & $135,672,570,340$ & 1.645 .796 .054 & 82 \\
\hline 2014 & 110.854 .933 .327 & 1.645 .796 .054 & 67 \\
\hline 2015 & 61.974 .000 & 1.645 .796 .054 & 37 \\
\hline
\end{tabular}

Sumber: Data Diolah 2019

Berdasarkan tabel 6 diatas pada PT. Buana Finance Tbk mengalami penurunan laba bersih selama 2 tahun berturut-turut, penurunan laba bersih tersebut berdampak pada penurunan nilai Earning per Share. Dapat diketahui bahwa nilai Earning per Share mengalami penurunan selama 2 tahun berturut - turut yakni pada tahun 2014 sampai 2015. Hal tersebut Pada tahun 2013 laba bersih perusahaan sebesar 135.672.570.340 dan jumlah saham yang beredar sebesar 1.645.796.054 menghasilkan perhitungan nilai Earning per Share sebesar 82. Kemudian pada tahun 2014 laba bersih perusahaan mengalami penurunan dari 135.672.570.340 menjadi 110.854.933.327 akan tetapi, jumlah saham yang beredar tetap sebesar 1.645.796.054 dan hasil perhitungan nilai Earning per Share pada tahun 2014 mengalami penurunan dari 82 menjadi 67. Tahun 2015 mengalami penurunan laba bersih dari 110.854.933.327 menjadi 61.974.000.000 tetapi jumlah saham yang beredar tetap sebesar 1.645.796.054 dan hasil perhitungan nilai Earning per Share pada tahun 2015 mengalami penurunan yang cukup signifikan dari 67 menjadi 37.

\section{Dividen}

Dividen adalah laba yang dibagikan kepada pemegang saham berdasarkan hasil keputusan dalam RUPS sesuai dengan proporsi investor dan jenis modalnya, yang menjadi hak para investor. Dimana laba tersebut dapat berupa dividen tunai atau dividen saham yang dapat memaksimumkan nilai perusahaan disamping keputusan investasi dan struktur modal. Cara perhitungan Dividen pada PT Indomobil Multijasa Tbk tahun 2014 adalah sebagai berikut: 
$\begin{aligned} & \text { Dividen } \\ & \text { Per Share }\end{aligned} \quad \frac{\text { Jumlah Dividen yang dibayarkan }}{\text { Jumlah lembar Saham }}=\frac{24.310 .000 .000}{4.325 .000 .000}=5,6$

Dividen

$\begin{aligned} & \text { PayOut } \\ & \text { Ratio }\end{aligned} \quad \frac{\text { Dividend per Share }}{\text { Earning per Share }}=\frac{5,6}{29,06}=0,19 \times 100 \%=19 \%$

Tabel 7

Hasil Rekapitulasi Perhitungan Divden

\begin{tabular}{ccccc}
\hline Tahun & $\begin{array}{c}\text { Jumlah Dividen } \\
\text { yang dibayarkan }\end{array}$ & Jumlah Saham yang Beredar & $\begin{array}{c}\text { Dividen Per } \\
\text { Share }\end{array}$ & $\begin{array}{c}\text { Dividen } \\
\text { PayOut } \\
\text { Ratio }\end{array}$ \\
\hline 2013 & 0 & 4.325 .000 .000 & 0 & 0 \\
\hline 2014 & 24.310 .000 .000 & 4.325 .000 .000 & 5,6 & $19 \%$ \\
\hline 2015 & 25.085 .000 .000 & 4.325 .000 .000 & 5,8 & $30 \%$ \\
\hline
\end{tabular}

Sumber : Data Diolah, 2019

Berdasarkan tabel 7 diatas pada PT. Indomobil Multijasa Tbk membagikan dividen selama 2 tahun yaitu pada tahun 2014 dan 2015. Pada tahun 2013 berdasarkan Rapat Umum Pemegang Saham (RUPS) para pemegang saham sepakat tidak membagikan dividen. Pembagian dividen PT Indomobil Multijasa Tbk pada tahun 2014 jumlah dividen yang dibayarkan sebesar 24.310.000.000 dan jumlah saham yang beredar sebesar 4.325.000.000 menghasilkan nilai Dividen Per Share sebesar 5,6 per saham dan rasio pembayaran dividen (Dividen PayOut Ratio) sebesar 19\%. Kemudian pada tahun 2015 jumlah dividen yang dibayarkan meningkat dari tahun sebelumnya sebesar 25.085.000.000 dan jumlah saham yang beredar tetap menghasilkan nilai Dividen Per Share perusahaan sebesar 5,8 per saham dan rasio pembayaran dividen (Dividen PayOut Ratio) sebesar 30\%

Tabel 8

Hasil Rekapitulasi Perhitungan Divden

\begin{tabular}{ccccc}
\hline Tahun & $\begin{array}{c}\text { Jumlah Dividen yang } \\
\text { dibayarkan }\end{array}$ & Jumlah Saham Yang Beredar & $\begin{array}{c}\text { Dividen } \\
\text { Per } \\
\text { Share }\end{array}$ & $\begin{array}{c}\text { Dividen } \\
\text { PayOut } \\
\text { Ratio }\end{array}$ \\
\hline 2013 & 5.000 .000 .000 & 1.000 .000 .000 & 5 & $13 \%$ \\
\hline 2014 & 5.000 .000 .000 & 1.012 .134 .340 & 4,9 & $12 \%$ \\
\hline 2015 & 0 & 1.012 .134 .340 & 0 & 0 \\
\hline
\end{tabular}

Sumber : Data Diolah, 2019 
Berdasarkan tabel 8 diatas pada PT. Batavia Prosperindo Tbk membagikan dividen selama 2 tahun yaitu pada tahun 2013 dan 2014. Pembagian dividen PT Batavia Prosperindo Tbk pada tahun 2013 jumlah dividen yang dibayarkan sebesar 5.000.000.000 dan jumlah saham yang beredar sebesar 1.000.000.000 menhasilkan nilai Dividen Per Share sebesar 5 per saham dan rasio pembayaran dividen (Dividen PayOut Ratio) sebesar 13\%. Kemudian pada tahun 2014 jumlah dividen yang dibayarkan tetap tidak berubah dari tahun sebelumnya sebesar 5.000.000.000 tetapi jumlah saham yang beredar mingkatkan dari tahun sebelumnya sebesar 1.012.132.340 menghasilkan nilai Dividen Per Share sebesar 4,9 dan rasio pembayaran dividen (Dividen PayOut Ratio) sebesar 12\% menurun dari tahun sebelumnya. Pada tahun 2015 berdasarkan Rapat Umum Pemegang Saham (RUPS) para pemegang saham sepakat tidak membagikan dividen.

Tabel 9

Hasil Rekapitulasi Perhitungan Divden

\begin{tabular}{ccccc}
\hline Tahun & $\begin{array}{c}\text { Jumlah Dividen } \\
\text { yang dibayarkan }\end{array}$ & $\begin{array}{c}\text { Jumlah Saham Yang } \\
\text { beredar }\end{array}$ & $\begin{array}{c}\text { Dividen } \\
\text { Per Share }\end{array}$ & $\begin{array}{c}\text { Dividen Pay Out } \\
\text { Ratio }\end{array}$ \\
\hline 2013 & 49.339 .658 .262 & 1.645 .796 .054 & 29 & $30 \%$ \\
\hline 2014 & 98.679 .424 .530 & 1.645 .796 .054 & 59 & $80 \%$ \\
\hline 2015 & 0 & 1.645 .796 .054 & 0 & 0 \\
\hline
\end{tabular}

Sumber : Data Diolah, 2019

Berdasarkan tabel 9 diatas pada PT. Buana Finance Tbk membagikan dividen selama 2 tahun yaitu pada tahun 2013 dan 2014. Pembagian dividen PT Buana Finance Tbk pada tahun 2013 jumlah dividen yang dibayarkan sebesar 49.339.658.262 dan jumlah saham yang beredar sebesar 1.645.796.054 menghasilkan nilai Dividen Per Share sebesar 29 per saham dan rasio pembayaran dividen (Dividen PayOut Ratio) sebesar 30\%. Kemudian pada tahun 2014 jumlah dividen yang dibayarkan meningkat dari tahun sebelumnya sebesar 98.679.424.530 dan jumlah saham yang beredar tetap. Menghasilkan nilai Dividen Per Share sebesar 59 dan rasio pembayaran dividen (Dividen PayOut Ratio) sebesar $80 \%$ mengalami peningkatan dari tahun sebelumnya. Pada tahun 2015 berdasarkan Rapat Umum Pemegang Saham (RUPS) para pemegang saham sepakat tidak membagikan dividen. 


\section{Hasil Perhitungan Earning per Share dan Tingkat Pengembalian Saham}

Tabel 10

Hasil Perhitungan Earning per Share dan tingkat pengembalian saham Tbk

\begin{tabular}{lccc}
\hline Tahun & Earning per Share & Dividen Per Share & Dividen PayOut Ratio \\
\hline 2013 & 31,36 & 0 & 0 \\
\hline 2014 & 29,06 & 5,6 & $19 \%$ \\
\hline 2015 & 18,98 & 5,8 & $30 \%$ \\
\hline
\end{tabular}

Sumber: Data Diolah 2019

Berdasarkan tabel 10 diatas diketahui bahwa PT Indomobil Multijasa Tbk selama tiga tahun berturut-turut kurang maksimal dalam memperoleh nilai Earning per Share. Karena dari hasil perhitungan Earning per Share menunjukan penurunan selama 2 tahun berturut turut, penurunan tersebut disebabkan oleh penurunan laba bersih dari tahun sebelumnya sehingga hasil perhitungan nilai Earning per Share mengalami penurunan. Namun untuk pembagian dividen pada tahun 2014 perusahaan membagikan dividen sebesar 5,6 per lembar saham dan rasio pembayaran dividen sebesar 19\% lebih baik dari tahun sebelumnya yang tidak membagikan dividen. Kemudian pada tahun 2015 mengalami kenaikan 5,8 perlembar saham dan rasio pembayaran dividen juga mengalami kenaikan sebesar 30\%. Dengan kejadian tersebut bisa diketahui bahwa perusahaan mengalami perkembangan dalam membagikan dividennya.

Tabel 11

Hasil Perhitungan Earning per Share dan Tingkat Pengembalian Saham

\begin{tabular}{cccc}
\hline Tahun & Earning per Share & Dividen Per Share & Dividen PayOut Ratio \\
\hline 2013 & 36,28 & 5 & $13 \%$ \\
\hline 2014 & 40,25 & 4,9 & $12 \%$ \\
\hline 2015 & 63,5 & 0 & 0 \\
\hline
\end{tabular}

Sumber: data diolah 2019

Dari hasil perhitungan tabel 11 diatas diketahui bahwa PT Batavia Prosperindo Tbk pada tahun 2013 memperoleh nilai Earning per Share sebesar 36,28 dan memperoleh nilai Dividen per Share sebesar 5. Sedangkan untuk rasio pembayaran dividen (Dividen Payout Ratio) memperoleh nilai sebesar 13\%. Pada tahun 2014 perusahaan memperoleh nilai Earning per Share sebesar 40,25 meningkat dari tahun sebelumya, tetapi untuk perolehan nilai Dividen per Share sebesar 4,9 dan rasio pembayaran dividen (Dividen Payot Ratio) memperoleh nilai sebesar 12\% 
mengalami penurunan dari tahun sebelumnya. Penurunan tersebut dikarenakan pada tahun 2014 jumlah harga saham beredar naik sebesar 1.012.134.340 yang berdampak pada penurunan nilai Dividen per Share dan rasio pembayaran dividen (dividen Payout Ratio). Sedangkan untuk tahun 2015 berdasarkan Rapat Umum Pemegang Saham (RUPS) para pemegang saham sepakat tidak membagikan dividen. Dengan begitu perusahaan kurang maksimal dalam pengembalian sahamnya.

Tabel 12

Hasil Perhitungan Earning per Share dan Tingkat Pengembalian Saham

\begin{tabular}{cccc}
\hline Tahun & Earning per Share & Dividen Per Share & Dividen PayOut Ratio \\
\hline 2013 & 82 & 29 & $30 \%$ \\
\hline 2014 & 67 & 59 & $80 \%$ \\
\hline 2015 & 37 & 0 & 0 \\
\hline
\end{tabular}

Sumber: data diolah 2019

Dari hasil perhitungan tabel 12 diatas diketahui bahwa PT Buana Finance Tbk pada tahun 2013 memperoleh nilai Earning per Share sebesar 82 dan memperoleh nilai Dividen per Share sebesar 29. Sedangkan untuk rasio pembayaran dividen (Dividen Payout Ratio) memperoleh nilai sebesar 30\%. Pada tahun 2014 perusahaan memperoleh nilai Earning per Share sebesar 67 mengalami penurunan dari tahun sebelumya, tetapi untuk perolehan nilai Dividen per Share sebesar 59 dan rasio pembayaran dividen (Dividen Payot Ratio) memperoleh nilai sebesar $80 \%$ mengalami kenaikan dari tahun sebelumnya. Sedangkan untuk tahun 2015 berdasarkan Rapat Umum Pemegang Saham (RUPS) para pemegang saham sepakat tidak membagikan dividen. Dengan begitu perusahaan kurang maksimal dalam pengembalian sahamnya.

\section{PEMBAHASAN}

Hasil penelitian diatas menunjukan bahwa ketiga perusahaan pada tahun 2013-2015 dikatakan kurang baik dalam pengembalian sahamnya. Karena memiliki nilai Earning per share dibawah standar rata rata industri, dimana nilai Earning per Share tersebut berdampak pada tingkat pengembalian saham. Kondisi tersebut sesuai dengan pendapat Kasmir (2015) bahwa earning per share adalah rasio laba perlembar saham atau disebut juga rasio nilai buku merupakan rasio untuk mengukur keberhasilan manajemen dalam mencapai keuntungan bagi para pemegang saham. 
Sebagaimana teori yang diungkapkan pada awal penelitian, bahwa Earning per Share berkaitan dengan Dividen. Karena besar kecilnya nilai Earning per Share merupakan informasi yang dianggap paling mendasar dalam menentukan keputusan investor dalam berinvestasi. Selain itu besar kecilnya nilai Earning per Share akan mendasari perusahaan untuk mengambil sebuah keputusan dalam pembagian dividen. Hal ini dibuktikan dari hasil penghitungan Earning per Share dan Dividen diatas. Oleh karena itu para investor seringkali memusatkan perhatiannya pada besarnya Earning Per Share dalam melakukan analisis saham. Jika Earning Per Share (EPS) tinggi maka keuntungan yang dihasilkan oleh perusahaan juga akan tinggi.

\section{SIMPULAN}

Dari hasil penelitian dan pembahasan yang ditelah dilakukan maka, simpulan penelitian ini sebagai berikut: tingkat pengembalian saham ketiga perusahaan menggunakan metode EPS menunjukan bahwa besar kecilnya EPS berperan penting dalam tingkat pembagian dividen.

\section{DAFTAR PUSTAKA}

Fahmi, I. (2014). Analisis Kinerja keuangan . Bandung: Alfabeta.

Hermawan, D., A. (2012). Pengaruh Debt to Equity Ratio, Earning Per Share dan Net Profit Margin terhadap Return Saham.

Kasmir. (2015). Analisis Laporan Keuangan . Jakarta: PT Raja Grafino Persada.

Raharjo. (2010). Keuangan dan Akuntansi untuk Manajer Non Keuangan. Yogyakarta: Graha Ilmu.

Tandelilin, \& Eduardus. (2010 ). Teori dan Aplikasi. Yogyakarta: Kanisius. 